\title{
The Influence of Corporate Governance on Potential Financial Distress on Transportation Companies listed on the Indonesia Stock Exchange for the period 2013-2017
}

Elisabeth Juliana Lelu ${ }^{1}$, Hakiman Thamrin ${ }^{2}$

${ }^{1}$ Mercu Buana University, Indonesia

${ }^{2}$ Mercu Buana University, Indonesia

Email: hakiman_00@yahoo.co.id; ejnamang@gmail.com

\begin{abstract}
This study aims to empirically examine the effect of characteristics corporate governance (managerial ownership, institutional ownership, board of commissioners, independent commissioners, board of commissioners, audit committee) on financial distress. This study uses data collection methods using the method of library research. In this study the type of secondary data used is in the form of financial statements from transportation companies listed on the Indonesia Stock Exchange in the period 2013-2017. Research data is data that is presented in time series. Data analysis was performed through descriptive statistical tests, followed by testing the feasibility of the regression model, testing the overall Fit Test model, the coefficient of determination test, and the classification matrix. Logistic regression analysis is used because the dependent variable used in this study is a dummy variable, which is a company with the possibility of financial distress. The results of this study indicate that: Managerial ownership has a significant effect on financial distress, Institutional ownership is proven to have a significant influence on financial distress, the Board of Commissioners is proven to have a significant influence on financial distress, independent commissioners is proven to have a significant influence on financial distress, The board of directors is proven to have a significant influence on financial distress and the Audit Committee is proven to have a significant effect on financial distress.
\end{abstract}

\section{Coresponden Author:}

Email: hakiman_00@yahoo.co.id Article with open access under license

\section{INTRODUCTION}

In today's globalization era, where industry competition is so high that many companies are insolvent due to intense competition, it is very important for companies to predict the financial distress conditions of companies to predict the early signs of bankruptcy as an early part of the early warning system for management.

Indonesia's economy is currently facing challenges such as the global economic slowdown, the weakening rupiah exchange rate and higher inflation. So that it can have an impact on indonesia's economic condition and can make business conditions will not be better than previous years (Kompasiana.com). Not only rivaled by the manufacturing industry, property and others who are experiencing intense competition but in companies engaged in transportation are also affected by the high global competition. Especially in the midst of such intense competition, especially in companies engaged in transportation will be more vulnerable to financial difficulties if management mis-manages it properly. At this time the implementation of good corporate governance is one of the factors that can affect the company's performance.

The transportation system cannot run efficiently if it is not supported by good economic development. This happened in 2008 where economic turmoil in Indonesia had an impact on the transportation sector. The increase in oil prices in 2008 above US $\$ 90 /$ barrel contributed greatly to the increase in the company's operating costs so that they forced the company to increase its service rates. In addition, sluggish market conditions due to the rise of a number of goods needs of the community has affected the purchasing power of the public towards the use of transportation. Such conditions if not handled will disrupt the company's cash flow which will ultimately lead to investor distrust of investment in the transportation sector. Corporate governance itself in Indonesia was officially introduced in 1990 and became widely in 1997.

when the economic crisis hit Indonesia. The 
impact of the crisis is the number of companies that went into bankruptcy because they were unable to survive, poor corporate governance is considered as one of the causes of the indonesian political economic crisis that began in 1997 whose effects are still felt today.

Recognizing such situations and conditions, the Government of Indonesia gives a strong boost to the implementation of corporate governance in Indonesia. Evidence of the government's concern can be seen from the making of various regulations governing good corporate governance. Where the government established a national committee on corporate governance policy (KNKCG) through the decree of the coordinating minister of equine number: KEP/31/M.EKUIN/08/1999 on the establishment of KNKCG. This was followed by the establishment of a national committee on governance policy in lieu of KNKCG through a decree of the Coordinating Minister for Economic Affairs number: KEP/49/M.EKON/11/2004.

Financial distress is a situation where the company's financial condition continues to decline every year. If the state of the company is approaching financial distress, usually the management of the company takes the decision to close all activities in the company whether it is production activities or other operational activities before bankruptcy or often called liquidation (Widyasaputri, 2012). According to Parker et al, (2002) and Abdullah, (2006), If the company can carry out corporate governance practices then it can protect the company against financial distress risks.

The transportation sector is a concern to be used as an object of research, because transportation companies are service companies that many people will need such transportation services. So that the sustainability of the business of transportation companies must be able to survive continuously. However, the facts in the field show that many transportation companies make a loss each period This indicates that the condition of the company can not be said well. Persistent losses indicate a company will not be able to meet its obligations. If it is left constantly it will lead to the bankruptcy of a company. Here are some transportation companies that went bankrupt because they could not maintain their business continuity. The companies include indonesian airlines Batavia Air, Bouraq Airlines, Jatayu Airlines, Indonesian Airlines, Sempati Airlines and Adam Air as reported in www.kompas.com on January 31, 2013. Based on the background of the problem that has been described, the problem formulation in this study is as follows:

1. Does managerial ownership affect financial distress?
2. Does Institutional ownership affect financial distress?

3. Does the size of the board of commissioners affect financial distress?

4. Does the proportion of independent commissioners affect financial distress?

5. Does the board of directors have any interest in financial distress?

6. Does the audit committee affect financial distress?

\section{A. Agency Theory}

According to Jensen and meckling (1976) in Hanifah (2013) The agency theory explains in an agency relationship, there is a contract between one party, namely the owner (principal), and the other party, namely the agent. Under the contract, the agent is bound to provide services for the owner. Based on the delegation of authority of the owner to the agent, management as an agent is given the right to make business decisions for the benefit of the owner. The interests of the two parties are not always in line so as to cause a conflict of interest between the principal and the agent as the authorized party to manage the company. Conflicts that occur between agents and principals are caused by information asymmetry. Information asymmetry occurs when managers as internal parties have more information than stakeholders as external parties.

\section{B. Understanding Corporate Governance}

According to the Cadbury committee (1992) defines corporate governance as a system that directs and controls the company with the aim of achieving a balance between the power of authority required by the company, to ensure the continuity of its existence and accountability to srakeholders. This relates to the authority regulations of owners, directors, managers, shareholders and so on (Surya and Yustiviadana, 2008:24).

\section{C. understanding Corporate Governance}

Managerial Ownership $(\mathrm{KM})$ is a share ownership owned by the management or manager of the company. Share ownership by managers in the company makes managers have a dual function, namely as the owner of the company and also the manager of the company (Mayangsari, 2015). With managerial ownership, decision making related to the company will be carried out with full responsibility because it is in accordance with the interests of management as one of the components of the company. Ownership by management will also increase control over the company's management (Hermawan, 2013). This variable indicator is measured by: 


\section{Understanding Institutional Ownership}

Institutional Ownership (KI) greater than (more than $5 \%$ ) will provide better ability to monitor management (Hermawan, 2013). The greater institutional ownership will be the more efficient the use of company assets so that the potential financial difficulties can be minimized. This is because the greater the institutional ownership will be the greater the monitor carried out against the company (Muharam and Triwahyuningtias, 2012). This variable indicator is measured by:

\section{E. Understanding of the Board of Commissioners}

The Board of Commissioners (DK) is an organ of the company that performs the monitoring function of the implementation of the board of directors' policy. The role of the commissioner is expected to minimize the agency's problems arising between the board of directors and shareholders, therefore it is expected that the board of commissioners can supervise the performance of the board of directors so that the resulting performance is in accordance with the interests of shareholders (Triwahyuningtias, 2012).

According to KNKG (2006) defines the board of commissioners as the highest internal control mechanism that is collectively responsible for conducting supervision and giving input to the board of directors and prove that the company conducts good corporate governance. This variable indicator is measured by:

$D K=D K$ Internal $+D K$ Eksternal

F. Understanding the Independent Council

In Decisions Ketua Bapepam No. 29/PM/2004, Komisaris Independen (KI) defined as a member of the that : (i) from outside the issuer or public company, (ii) does not have direct or indirect shares in the company, (iii) has no affiliation with the issuer or public company, commissioner, director, or major shareholder of the issuer or public company, (iv) and has no business relationship either directly or indirectly related to the business activities of the issuer or the company. Amirudin (2004) explained, since Indonesia is mired in economic crisis, corporate governance becomes part of the improvement of corporate management. An active and independent board is indispensable to ensure the best standards of corporate governance.. This variable indicator is measured by:
$I C=\frac{\text { Jumlah Komisaris Independen }}{\text { Jumlah Dewan Komisaris }}$

\section{G. Understanding the Board of Directors}

The board of directors is one of the corporate governance mechanisms needed to overcome the agency problems that exist within the company. The larger the board of directors, it is expected that the better the quality of decisions produced, so that it will have an impact on the company's performance that can reduce financial distress. In Purwanto and Hanifah (2013) stated that the larger the number of directors, the smaller the company experienced financial distress. The board of directors of a company will determine the policy to be taken or the company's strategy in the short and long term (Mayangsari, 2015).This variable indicator is measured by :

\section{$D D=$ Jumlah Dewan Direksi}

\section{H. Understanding the Audit Committee}

Audit Committee (KA) is a committee formed by and responsible to the board of commissioners in helping to carry out the duties and functions of the board of commissioners. The audit committee is chaired by an independent commissioner. The audit committee consists of at least 3 (three) members from independent commissioners and outside issuers or public companies. (Keputusan Ketua Bapepam -LK No. KEP$643 / \mathrm{BL} / 2012)$. This variable indicator is measured by:

\section{KA = Jumlah Komite Audit}

\section{Understanding Financial Distress}

Financial Distress is a situation where the company's operating cash flow is inadequate to pay off current liabilities (such as trade payables or interest expenses) and the company is forced to take corrective measures (Hapsari, 2012). Bankruptcy is a situation where the company has a lack and inadequacy of funds to run or continue its business, the more serious consequences of bankruptcy is the closing of the business or liquidation. This variable indicator is measured by:

Score $0=$ Companies experiencing Financial Distress

Score $1=$ Companies that do not experience Financial Distress.

\section{Frame of Mind}

Where in this study, dependent variables $(Y)$ used are financial distress, while independent variables $(X)$ are used namely managerial ownership, institutional ownership, board of commissioners, independent commissioners, board of directors and audit committee. Based 
on the description above can be described the frame of mind as follows: 



\section{Hypothesis}

Based on background, problem formulation and frame of mind, the action hypotheses used in this study are:

1) First Hypothesis

H1 : Managerial Ownership affects financial distress

2) Second Hypothesis

H2 : Institutional ownership affects financial distress

3) Third Hypothesis

H3 : Board of Commissioners affect financial distress

4) The Fourth Hypothesis

H4 : Independent Commissioner affects financial distress

5) The Fifth Hypothesis

H5 : Board of Directors affects financial distress

6) Sixth Hypothesis

H6 : Audit Committee affects financial distress.

\section{METHOD}

The time of the research was carried out since April 2018 until the research writing limit that has been listed. This research was conducted in Transportation companies listed on the Indonesia Stock Exchange (IDX) in the period of research period 2013-2017. Research data obtained from the official website Bursa Efek Indonesia (BEI), i.e http://www.idx.co.id.

This type of research is a kausal research that aims to test hypotheses about the influence of one or several variables (independent) on other variables (dependents). To test the influence of Corporate Governance on the possibility of financial distress. This research uses data collection method using Literature Research method. In this research, the secondary data type used is in the form of financial statements from transportation companies listed on the Indonesia Stock Exchange in the period 2013-2017. Research data is data presented in a time series (between times).
Data analysis is conducted through descriptive statistical test, followed by regression model feasibility test, Fit Test overall test, determination coefficient test, and classification matrix.

Logisic regression analysis is used because the dependent variables used in this study are dummy variables, namely companies with the possibility of financial distress. The regression model to be used in this study is as follows::

$$
\begin{gathered}
Y=a+\beta 1 X 1+\beta 2 X 2+\beta 3 X 3+\beta 4 X 4+ \\
\beta 5 X 5+\beta 6 X 6+\varepsilon
\end{gathered}
$$

Where:

$\mathrm{Y}=$ Financial Distress

$\mathrm{a}=$ konstant

X1 = Managerial Ownership

$\mathrm{X} 2$ = Instutional Ownership

$\mathrm{X} 3=$ Board of Commissioners

X4 = Independent Commissioner

X5 $=$ Board of Directors

$\mathrm{X} 6$ = Audit Committee

$\varepsilon=$ Residual

The test level uses a a (alpha) of $5 \%$ and data processing is carried out with SPSS Version 22 software. Coefficient Test Determination is used to find out how much bound variable variation is influenced by the free variable variation that can be seen from the $R$-square value $\left(R^{2}\right)$.

$$
R_{\text {Nagelkerke }}^{2}=\frac{1-\left(\frac{L_{0}}{L_{1}}\right)^{2 / n}}{1-L_{0}^{2 / n}}
$$

The coefficient value of determination (Nagelkerke R Square) is a test conducted to find out how much independent variables are able to explain and affect dependent variables. Nagelkerke $\mathrm{R}$ Square is a modification of the Cox and Snell coefficient which is a measure that tries to mimic the size of R2 in multiple regressions. Nagelkerke R Square values vary between 1 (one) and 0 (zero). The closer the value of 1 , the model is considered the betterness of fit while the closer to 0 then the model is less goodness of fit (Ghozali, 2009).

\section{RESULT AND DISCUSSION Test Assumptions Descriptive Statistical Analysis}

\begin{tabular}{|c|c|c|c|c|c|}
\hline \multicolumn{6}{|c|}{ Descriptive Statistics } \\
\hline & $\mathrm{N}$ & Minimum & Maximum & Mean & Std. Deviation \\
\hline Kepemilikan Manajerial & 135 & .000 & .702 & .05276 & .145250 \\
\hline Kepemilikan Institusional & 135 & .111 & 1.700 & 67050 & 234058 \\
\hline Dewan Komisaris & 135 & 2.000 & 8.000 & 3.47407 & 1.418585 \\
\hline Komisaris Independen & 135 & .200 & 1.000 & .41985 & .150942 \\
\hline Dewan Direksi & 135 & 2.000 & 9.000 & 4.21481 & 1.640828 \\
\hline Komite Audit & 135 & 2.000 & 4.000 & 2.82222 & .530652 \\
\hline Financial Distress & 135 & .00 & 1.00 & .4444 & .49875 \\
\hline Valid N (listwise) & 135 & & & & \\
\hline
\end{tabular}

Descriptive statistical test results can be seen in the Table below.

Based on the results of descriptive statistical testing in the table above, it is known that the research sample $(N)$ is as much as 135 , then it can be explained that the financial distress variable is 
measured using dummy variables where the minimum value of 0 means that obtaining profit and a maximum value of 1 means that the company loses. Meanwhile, the average value (mean) obtained by financial distress variables is 0.4444 with a standard deviation of 0.49875 . Therefore, it can be concluded that descriptive statistical analysis is used because it meets the assumption of earning profit.

\section{Regression Model Feasibility Test Results}

\begin{tabular}{|l|r|r|r|}
\multicolumn{5}{|c|}{ Hosmer and Lemeshow Test } \\
\hline Step & Chi-square & df & Sig. \\
\hline 1 & 3.918 & & 8 \\
\hline
\end{tabular}

Sumber: Hasil Olah Data SPSS 22 (2019)

The feasibility of the regression model was assessed using Hosmer and Lemeshow's Goodness of Fit Test. If the significance value of Hosmer and Lemeshow's goodness of fit statistic > 0.05 means that the model can predict its observation value or can be said that the model can be accepted because it matches the observation data, whereas if the significance value of Hosmer and Lemeshow's goodness of fit statistic $<0.05$ means there is a significant difference between the model and its observation value so that the goodness fit model is not good because the model cannot be used to predict.

Thus, it can be concluded that the test results of Hosmer and Lemeshow's Goodnes of Fit in the Table obtained a significant value of $0.864>0.05$ (a) which means the model can predict the observation value or it can be said that the model is acceptable because it matches the observation data.

\section{Fit Model Overall Test}

The overall test of this model is calculated from the difference of -2LL values between models with only consisting of constants and estimated models consisting of independent constants and variables, -2LL tests follow the chi square distribution with degrees of freedom. Hypotheses for assessing fit models are:

$\mathrm{HO}$ : Model hypothesized fit with data

$\mathrm{H} 1$ : The hypothesized model is not fit with the data

Based on the output of spss, the test results of the overall FIT model can be shown in the table below

\begin{tabular}{|l|l|r|r|r|}
\multicolumn{5}{|c|}{ Omnibus Tests of Model Coefficients } \\
\hline \multirow{3}{*}{ Step 1 } & Chi-square & \multicolumn{1}{|c|}{ df } & \multicolumn{1}{c|}{ Sig. } \\
\hline & Step & 126.667 & 6 & .000 \\
\cline { 2 - 6 } & Block & 126.667 & 6 & .000 \\
\cline { 2 - 6 } & Model & 126.667 & 6 & .000 \\
\hline
\end{tabular}

Sumber: Hasil Olah Data SPSS 22 (2019)

Based on the table above, is a comparison view of the value -2 Log likelihood consisting of only constants and -2 Log likelihood consisting of independent constants and variables. The comparison follows the spread of chi square. Chi square value of 126,667 with df 6 with Sig value. Model by $0.00>0.05(5 \%)$ then it can be concluded that $\mathrm{HO}$ is accepted that the model hypothesized fit with data.

\section{Determination Coefficient Test}

The results of the determination coefficient test can be seen in the following table:

Based on the table above, it can be known that the value of Nagelkerke $R$ Square is 0.815 $(81.5 \%)$. These results showed that independent variables of managerial ownership, institutional ownership, board of commissioners, independent commissioners, board of directors and audit committee were able to explain and influence financial distress by $81.5 \%$ and the remaining $19.5 \%$ were explained by other variables outside the research model. The result of the coefficient was diterminated by $81.5 \%$ based on real data of financial statements at transportation companies listed on the Indonesia Stock Exchange for the period 2013-2017, in addition, the value of the deterrential coefficient of $81.5 \%$ showed that quite a lot of other variables affected financial distress such as CSR, profitability ratio, liquidity, leverage and others.

\section{Classification Matrix}

The results of the classification matrix can be seen in the following table:

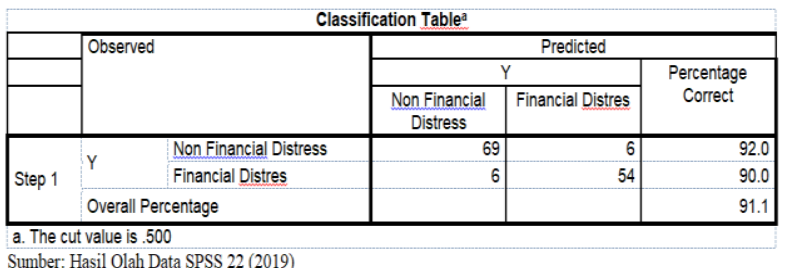

Based on the Table shows the predictive strength of the regression model to predict the probability of financial distress receipts is $90.0 \%$. This means that by using the proposed regression model, it is predicted that there are 60 data from 27 samples $(90.0 \%)$ used to see predictions that will experience financial distress. While the model that does not experience financial distress is $92.0 \%$, which means that with the proposed regression model is predicted there are 75 data from 27 sample companies (92.0\%) predicted will not experience financial distress. Overall, $91.1 \%$ can be precisely predicted by this logistic regression model.

\section{Logistic Regression Analysis}

The results of logistic regression test that formed can be seen in the following table by using 
computer software calculation namely SPSS (Statistical Package for Social Science) version 22:

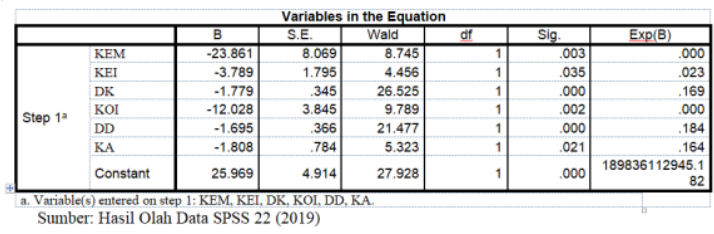

Based on the table above, the regression equation can be created as follows.

FD $=25.969-23,861$ KEM - 3,789 KEI - 1,779 DK - 12,028 KOI -1,695 DD - 1,808 KA + $\mathrm{e}(0,05)$

Based on the results of the logistics regression test above, it can be explained that of the six corporate governance variables tested, it is proven that the six variables (all) namely managerial ownership, institutional ownership of the board of commissioners, independent commissioners, board of directors and audit committee have a significant influence on financial distress on transportation companies registered with idx.

\section{Hypothesis Test}

Hypothetical tests are conducted to determine the influence of each independent variable on its dependent variables. Basic decision making based on significance value, if the value is significantly less than the error rate of $5 \%(\mathrm{sig} .<0.05)$ then $\mathrm{Ho}$ is rejected. Test results can be briefly viewed in the following Table.

\begin{tabular}{|c|c|c|c|}
\hline \multicolumn{4}{|c|}{ Hasil Uji Hipotesis } \\
\hline No & Variabel & B & Sig. \\
\hline 1 & Kepemilikan Manajerial (KEM) & -23.861 & .003 \\
\hline 2 & Kepemilikan Institusional (KEI) & -3.789 & .035 \\
\hline 3 & Dewan Komisaris (DK) & -1.779 & .000 \\
\hline 4 & Komisaris Independen (KOI) & -12.028 & .002 \\
\hline 5 & Dewan Direksi(DD) & -1.695 & .000 \\
\hline 6 & Komite Audit (KA) & -1.808 & .021 \\
\hline
\end{tabular}

Sumber: Hasil Olah Data SPSS 22 (2019)

\section{First Hypothesis (H1)}

The first hypothesis tests the influence of managerial ownership on financial distress on transportation companies listed on the Indonesia Stock Exchange for the period 2013-2017. So the hypotheses juked in this study are as follows:

Ha1 = Managerial ownership affects financial distress

Ho1 = Managerial ownership has no effect on financial distress

Based on the test results in the Table of significance obtained managerial ownership variable of $0.003<0.05$ and regression coefficient value of 23.861. Thus Ho1 was rejected and Ha1 accepted. The results of the first hypothesis show that managerial ownership variables have a significant negative effect and are related to financial distress to transportation companies listed on the Indonesia Stock Exchange for the period 2013-2017.

\section{Second Hypothesis (H2)}

The second hypothesis tests the influence of institutional ownership on financial distress on transportation companies listed on the Indonesia Stock Exchange for the period 2013-2017. So the hypotheses juked in this study are as follows:

$\mathrm{Ha} 2$ = Institutional ownership affects financial distress

$\mathrm{Ho} 2$ = Institutional ownership has no effect on financial distress

Based on the test results in the Table of significance obtained institutional ownership variable of $0.0035<0.05$ and regression coefficient value of $-3,789$ Thus $\mathrm{Ho} 2$ is rejected and $\mathrm{Ha} 2$ is accepted. The results of the second hypothesis show that institutional ownership variables have a significant negative effect and are related to financial distress to transportation companies listed on the Indonesia Stock Exchange for the period 2013-2017.

\section{Third Hypothesis (H3)}

The third hypothesis tests the influence of the board of commissioners on financial distress on transportation companies listed on the Indonesia Stock Exchange for the period 2013-2017. So the hypotheses juked in this study are as follows:

$\mathrm{Ha} 3=$ Board of Commissioners affects financial distress

Ho3 = Board of Commissioners has no effect on financial distress

Based on the test results, the significance value obtained by the board of commissioners variable is $0.000<0.05$ and the regression coefficient value is $-1,779$. Thus Ha3 was accepted and $\mathrm{Ho} 3$ rejected. The results of the third hypothesis show that the variables of the board of commissioners have a significant negative effect on financial distress to transportation companies listed on the Indonesia Stock Exchange for the period 2013-2017.

\section{Fourth Hypothesis (H4)}

The fourth hypothesis tests the influence of independent commissioners on financial distress on transportation companies listed on the Indonesia Stock Exchange for the period 2013-2017. So the hypotheses juked in this study are as follows:

$\mathrm{Ha} 4$ = Independent commissioner affects financial distress

Ho4 = Independent commissioner has no effect on financial distress

Based on the test results of significance value obtained by independent commissioner variables of $0.002<0.05$ and regression coefficient value of 12.028. Thus $\mathrm{Ha} 4$ was accepted and $\mathrm{Ho} 4$ rejected. The results of the fourth hypothesis show that independent commissioner variables have a significant negative effect on financial distress to 
transportation companies listed on the Indonesia Stock Exchange for the period 2013-2017.

\section{Fifth Hypothesis (H5)}

The fifth hypothesis tests the influence of the board of directors on financial distress on transportation companies listed on the Indonesia Stock Exchange for the period 2013-2017. So the hypotheses juked in this study are as follows:

$\mathrm{Ha} 5=$ Board of Directors affects financial distress

$\mathrm{Ho5}=$ The board of directors has no effect on financial distress

Based on the test results in Table 4.10 the significance value obtained by the board variable is $0.000<0.05$ and the regression coefficient value is 1.695. Thus Ha5 was accepted and Ho5 rejected. The results of the fifth hypothesis show that the variables of the board of directors have a significant negative effect on financial distress to transportation companies listed on the Indonesia Stock Exchange for the period 2013-2017.

\section{Sixth Hypothesis $(\mathrm{H} 6)$}

The sixth hypothesis tests the influence of the audit committee on financial distress on transportation companies listed on the Indonesia Stock Exchange for the period 2013-2017. So the hypotheses juked in this study are as follows:

$\mathrm{Ha} 6=$ Audit committee affects financial distress Ho6 = Audit committee has no effect on financial distress

Based on the test results, the significance value obtained by the audit committee variable was $0.021<0.05$ and the regression coefficient value was $-1,808$. Thus Ha6 was accepted and Ho6 rejected. The results of the sixth hypothesis show that audit committee variables have a significant negative effect on financial distress to transportation companies listed on the Indonesia Stock Exchange for the period 2013-2017.

\section{Discussion of Research Results}

Based on the results of logistics regression analysis conducted shows that partially the variables of managerial ownership and ownership have a significant effect on financial distress. Meanwhile, the board of commissioners, independent commissioners, and audit committee have no significant effect on financial distress. Meanwhile, the board of directors has no effect on financial distress. Here is a table that summarizes the relationships that occur in independent variables to their dependent variables.

\begin{tabular}{|c|c|c|}
\hline $\begin{array}{l}\text { Hubungan Variabel Independen terhadap Variabel Op } \\
\text { Going Concern }\end{array}$ & \multicolumn{2}{|c|}{ Hubungan Variabel Independen terhadap Variabel Opini Audit } \\
\hline & Variabel & Signifikansi \\
\hline & Kepemilikan Manajerial (KEM) & Signifikan \\
\hline & Kepemilikan Institusional (KEI) & Signifikan \\
\hline & Dewan Komisaris (DK) & Signifikan \\
\hline & Komisaris Independen (KOI) & Signifikan \\
\hline & Dewan Direksi (DD) & Signifikan \\
\hline & Komite Audit (KA) & Signifikan \\
\hline
\end{tabular}

Based on the table above, the research results can be analyzed as follows:
1. The results showed that managerial ownership has a significant effect on financial distress

This means that the higher the level of managerial ownership in the company, the possibility of financial distress decreases. The ability of managerial ownership in predicting financial distress can be caused by the ownership of shares by the management will provide additional incentives to management in supervising the policies that have been set. With these additional incentives, it will reduce management's opportunistic behaviors and can align interests with other shareholders.

2. Institutional ownership is proven to have a significant influence on financial distress

The results of this study indicate that companies that have more institutional ownership can reduce the possibility of financial distress. With the greater share ownership by institutions, supervision of management performance will be greater. This means that management will perform their duties and make decisions with more care that avoids the possibility of financial distress.

3. The Board of Commissioners is proven to have a significant negative influence with the direction of negative relations to financial distress.

This is because the increasing number of commissioners, it is likely that the decisionmaking will be effective, appropriate and fast and act independently in the sense that it has no interest that can interfere with its ability to carry out its duties independently and critically in relations with each other and to the board of directors will be difficult to materialize so that this will increase the potential for financial distress.

4. Independent commissioners are shown to have a significant negative influence on financial distress

In agency theory, independent commissioners are corporate governance mechanisms that can reduce problems in agency theory. Independent commissioners serve as examiners and balancers in improving the effectiveness of the board of commissioners which means that with the presence of independent commissioners, in addition to the supervision of management decision making by the board of directors, supervision is also carried out by independent external parties so that the decisions taken are appropriate.

5. The board of directors proved to have a significant negative influence on financial distress

The board of directors of a company will determine the policies or strategies that will be taken both short-term and long-term. The board of directors in a company plays a more 
emphasis on the monitoring function of the policy implementation.

6. The audit committee proved to have a significant negative influence on financial distress.

The audit committee is a corporate governance mechanism that is assumed to reduce agency problems that arise in a company. The audit committee is tasked to assist the board of commissioners in order to supervise the responsibilities of the company's management in the management of the company through information obtained from internal auditors.

\section{CONCLUSION}

Based on the results of data processing of all variables of managerial ownership, institutional ownership, board of commissioners, independent commissioners, board of directors and audit committee on financial distress at Transportation companies Listed on the Indonesia Stock Exchange Period 2013-2017, can be concluded as follows:

First, managerial ownership has a significant negative effect on financial distress to transportation companies listed on the Indonesia Stock Exchange for the period 2013-2017. The results of this study are in line with Hanafi and Breliastiti (2016) who said that managerial ownership has an influence on the occurrence of financial distress.

Second, institutional ownership has a significant effect on financial distress in transportation companies listed on the Indonesia Stock Exchange for the period 2013-2017. The results of this study are in line with radifan and Yuyetta research (2015) which also found the influence and significant influence of institutional ownership on the company's financial distress.

Third, the Board of Commissioners has a significant influence on financial distress to transportation companies listed on the Indonesia Stock Exchange for the period 2013-2017. The results of this study are contrary to the research of Deviacita and Achmad (2012) which stated that the size of the board of commissioners proved to have no effect on financial distress.

Fourth, independent Commissioners have a significant influence on financial distress in transportation companies listed on the Indonesia Stock Exchange for the period 2013-2017. The results of this study are different from the research of Putri and Merkusiwati (2014) which found that independent commissioners have no significant effect on financial distress.

Fifth, the Board of Directors has a significant influence on financial distress to transportation companies listed on the Indonesia Stock Exchange for the period 2013-2017. The results of this study are different from cinantya and
Merkusiwati research (2015) which stated that the number of board of directors has no influence on financial distress.

Sixth, the Audit Committee has a significant influence on financial distress to transportation companies listed on the Indonesia Stock Exchange for the period 2013-2017. The results of this study are different from Radifan and Yuyetta's research (2015) which stated that the size of the audit committee is not significant to the possibility of financial distress.

\section{REFERENCE}

Al-Matari E.M, Al-Swidi A. K, Bt Fadzil F.H. (2014) "The Measurements of Firm Performance's Dimensions", Asian Journal of Finance \& Accounting, 6 (1), 24-49.

Almilia, L. dan Kristijadi, E. 2003. Analisis Rasio Keuangan untuk Memprediksi Kondisi Financial Distress Perusahaan Manufaktur yang Terdaftar di Bursa Efek Jakarta. Jurnal Ekonomi dan Bisnis Vol. XII. No. 1, Maret 2006.

Amrullah, Khania Vissiani, "Prediksi Fincancial Distress Perusahaan (Studi Empirik Pada Perusahaan Manufaktur Yang Terdaftar di BEI) Periode 2001-2008". Skripsi Jurusan Manajemen, Fakultas Ekonomi dan Bisnis UIN Syarif Hidayatullah Jakarta, 2010.

Anggraini, T. V. 2010. Pengaruh Karakteristik Komite Audit Terhadap Financial Distress (Studi Empiris pada Perusahaan yang Terdaftar di Bursa Efek). Skripsi. Fakultas Ekonomi, Universitas Diponegoro.

Artikel financetoday, Indrajit, 06 April 2011, 10:27 WIB

Baldwin, C.Y. dan Scott P. M. (1983) "The resolution of claims in financial distress: The case of Massey-Ferguson". Journal of Finance. 38, (2), 505-516.

Brancato, C.K. \& Gaughan, P. (1991) Institutional Investors and Capi- tal Markets: 1991 Update (Columbia Law School Institu- tional Investor Project, New York, New York).

Brigham, Eugene F. dan Gapenski, Louis C. 1997. Financial Management Theory and Practice. Orlando: The Dryden Pres.

Brigham, E.F., \& Daves, P.R. (2003). Intermediate Financial Management with Thomson One. 
United States of America: Cengage SouthWestern.

Cadbury Committee, 1992. Report of The Financial Aspects of Corporate Governance, London, Gee.

Christiawan, Y. J. dan J. Tarigan. 2007. Kepemilikan Manajerial: Kebijakan Hutang, Kinerja dan Nilai Perusahaan. Jurnal Akuntansi dan Keuangan. Vol.1. Mei 2007. Hal: 1-8.

Deviacita, A.W. dan Achmad, T. 2012. "Analisis Pengaruh Mekanisme Corporate Governance Terhadap Financial Distress". Diponegoro Journal of Accounting, Vol.I, No.2.

E. Altman. 1983. Financial Ratios, Diskriminant Analysis and the Prediction of Corporate Bankruptcy. Journal of Accounting.

Effendi, Muh. Arief. 2009. The Power of Good Corporate Governance. Jakarta: Salemba Empat.

Elloumi, Fathi and Jean-Pierre Gueyie, 2001. Financial Distress and Corporate Governance: an Empirical Analysis. Corporate Governance. Bedford: 1(1): 15-23.

Fachrudin, Amalia Khoira. 2008. Kesulitan Keuangan Perusahaan dan Personal. Ejournal Universitas Negeri Surabaya.

Fachrudin, Khaira Amalia. 2008. Kesulitan Keuangan Perusahaan dan Personal. Medan: USU Press.

Fuad, Andhika Yudha, 2014. Analisis Pengaruh Penerapan Mekanisme Corporate Governance Terhadap Kemungkinan Perusahaan Mengalami Financial Distress. Diponegoro Journal of Accounting, Vol.3.No.4.

Ghozali, Imam, 2006. Aplikasi Analisis Multavariat dengan Program SPSS. Edisi Keempat, Badan Penerbit Universitas Diponegoro, Semarang.

Ghozali, Imam. 2009. Aplikasi Analisis Multivariate dengan Program SPSS. Edisi 4. Semarang: Badan Penerbit Universitas Diponegoro.

Hanifah, Oktita E. (2013). Pengaruh Struktur Corporate Governance Dan Financial Indicators Terhadap Kondisi Financial Distress.Skripsi Ilmiah Universitas Diponegoro.

Hanifah, O. E. dan Purwanto, A. 2013. Pengaruh Struktur Corporate Governance dan Financial Distress terhadap Kondisi Financial Distress.
Diponegoro Journal of Accounting 2 (2): 23373806.

Hermawan, Sigit dan Maharis Budi Wahyuaji. 2013. Analisis Pengaruh Intellectual Capital Terhadap Kemampulabaan Perusahaan Manufaktur Cunsomer Good Di Bursa Efek Indonesia. Jurnal Pendidikan Akuntansi. Hal. 271-282.

Hofer, C. W. (1980) "Turnaround Strategies", Journal of Business Strategy. 1, 19-31.

https://www.idnfinancials.com/id/CPGT/PT-CitraMaharlika-Nusantara-Corpora-Tbk

https://news.detik.com/berita-jawa-barat/d3560871/tuntut-hak-eks-karyawan-pt-cipagantigeruduk-pul-travel-di-bandung

Jensen, M. C dan W.H Meckling, 1976. "Theory of The Firm: Managerial Behaviour, Agency Cost and Ownership Structure". Journal of Financial Economics, Vol 3, pp 305-360

Kaihatu, Thomas S, "Good Corporate Governance dan Penerapanya di Indonesia", Jurnal Menajemen dan Kewirausahaan. Vol.8 No.1, Maret. Universitas Kristen Petra Surabaya, 2006.

KNKG. (2006). Pedoman Umum Good Corporate Governance Indonesia. Komite Nasional Kebijakan Governance. Komite Nasional Kebijakan Corporate Governance. (2001). Pedoman Umum Good Corporate Governance Indonesia. Jakarta.

Kusumawati, Diyah. 2008. Pengaruh Mekanisme Corporate Governance Terhadap Peringkat Obligasi dan Yield Obligasi. Skripsi Jurusan Manajemen, Fakultas Ekonomi dan IImu Sosial, Universitas Islam Negri Syarif Hidayatullah, Jakarta.

Li, Hong Xia, Zong Jun Wang dan Xiao Lan Deng, 2008, "Ownership, Independent Directors, Agency Costs and Financial Distress: Evidence from Chinese Listed Companies", Corporate Governance, Vol. 8 Iss: 5 pp 622-636.

Mahoney, L., Fauzi, H., and Rahman. 2007. Institutional Ownership and Corporate Social Performance: Empirical Evidence from Indonesian Companies. Issues in Social and Environmental Accounting Vol. 1, No. 2 December 2007 Pp 334-347.

Mayangsari, Lillananda Putri. 2015. Pengaruh Good Corporate Governance dan Kinerja Keuangan 
Terhadap Financial Distress. Jurnal IImu dan Riset Akuntansi, Vol.4, No: 4.

Nur DP, E. 2007. Analisis Pengaruh Praktek Tata Kelolah Perusahaan (Corporate Governance) terhadap Kesulitan Keuangan Perusahaan (Financial Distress: Suatu kajian empiris). Jurnal Bisnis dan akuntansi 9 (1), PP: 84-108.

Parker, S., Peters, G.F. and Turetsky, H.F. (2002) "Corporate Governance and Corporate Failure: A Survival Analysis", Corporate Governance: International Journal of Business in Society, 2 (2), 4-12

Parkinson, J.E. 1994. Corporate Power and Responsibility. Oxford: Oxford University Press.

Platt, H. D. dan Platt, M.B. (2002) "Predicting Corporate Financial Distress: Reflections on Choice-based Sample Bias, Journal of Economics and Finance, 26, 184-199.

Purnajaya dan Merkusiwati. 2014. Analisis Komparasi Potensi Kebangkrutan Dengan Metode Z-score Altman, Springate, dan Zmijewski pada Industri Kosmetik yang Terdaftar Di Bursa Efek Indonesia. Dalam EJurnal Akuntansi Universitas Udayana 7.1 (2014):48-63. ISSN: 2302- 8556

Putri, N.W.K.A dan Merkusiwati, N.K.L.A. 2014. "Pengaruh Mekanisme Corporate Governance, Likuiditas, Leverage, dan Ukuran Perusahaan Pada Financial Distress". E-Jurnal Akuntansi Universitas Udayana, 7.1.

Rezaee, Zabihollah. (2007). "Corporate Governance Post-Sarbanes Oxley". Hoboken: John Wiley and Sons.

Ross, Stephen A, Westerfield and Jaffe, 1999. Corporate Finance, Irwin Mc Graw Hill.

Sastriana, Dian, dan Fuad. 2013. "Pengaruh Corporate Governance dan Firm Size Terhadap Perusahaan yang Mengalami Kesulitan Keuangan (Financial Distress)". Diponegoro Journal of Accounting, Vol.2, No.3.

Sekaran, U., 2003, Research Methods for Business: Metodologi Penelitian Untuk Bisnis, Jakarta, Salemba Empat.
Shleifer, A. Dan R. Vishny. 1997.'A survey of corporate governance ', journal of finance vol. 52, hal. 737-783.

Solomon, J.2007. Corporate Governance And Accountability. 2 Ed.The Atrium, West Sussex: John Willey Sons, Ltd.

Sugiyono, 2011. Metode Penelitian Kuantitatif, Kualitatif dan R\&D. Bandung: Afabeta.

Sujarweni, V. Wiratna. 2014. Metode Penelitian: Lengkap, Praktis, dan Mudah Dipahami. Yogyakarta: Pustaka Baru Press.

Surya, Indra dan Ivan Yustiviandana, "Penerapan Good Corporate Govenance Mengesampingkan Hak Istimewa Demi Kelangsungan Usaha". Edisi 1. Jakarta: Kencana Prenanda Media Group, 2008.

Tjager, I.N., et al. 2003. Corporate Governance: Tantangan dan Kesempatan bagi Komunitas Bisnis Indonesia, Serial Mastering Good Corporate Governance. Jakarta: Prenhanllindo.

Triwahyuningtias, Meilinda dan Muharam, Harjum. 2012. Analisis Pengaruh Struktur Kepemilikan, Ukuran Dewan, Komisaris Independen, Likuiditas dan Leverage terhadap Terjadinya Kondisi Finacial Distress (Studi Pada Perusahaan Manufaktur Yang Terdaftar Di Bursa Efek Indonesia Tahun 20082010).JurnalManajemen,Vol. 1, No.1, h.1-14.

Wardhani, Ratna. 2006. Mekanisme Corporate Governance Dalam Perusahaan Yang Mengalami Permasalahan Keuangan. Simposium Nasional Akuntansi IX.

Warsono, Sony dkk, 2009, Corporate Governance Concept and Model, Yogyakarta: Center Of Good Corporate Governance.

Whitaker, R. B. 1999. "The Early Stages of Financial Distress". Journal of Economics and Finance, 23: 123-133.

Widyasaputri, Erlinda. (2012). Analasis Mekanisme Corpporate Governance pada Perusahaan yang Mengalami Kondisi Financial Distress.Accounting Analysis Journal.Vol. 1, No. 2, Halaman 1-8 